\title{
USING THE SOUTH AFRICAN EXCELLENCE MODEL TO FOCUS IMPROVEMENT STRATEGIES IN SOUTH AFRICA.
}

\author{
Bruce R Smit, Pr Eng
}

Witwatersrand Technikon, Johannesburg, Gauteng, South Africa

South African companies wish to join the world class family. As the Malcolm Baldrige Quality Award in the USA and the European Quality Award in Europe have been effected, the South African Quality Institute (SAQI) pioneered and developed a National Quality Award together with leading South African companies. The South African Award model is a full hybrid of the Malcolm Baldrige and European Foundation Quality models. The awards process is now managed by the South African Excellence Foundation. This model enables companies to assess their excellence levels and use benchmarks towards improved quality, service and costs. The model has been ratified by the administrators of both of the aforementioned awards. The criteria in the award lend themselves to measurement by self assessment. This paper explains the model and its application as a foundation to strategic planning.

\section{OPSOMMING}

Maatskapye in Suid Afrika moet op die wereldmark kan presteer. Amerika het die Malcolm Baldrige Kwaliteitstoekenning en Europa die Europese Kwaliteitstoekenning.vir uitmuntende prestasie in die besigheidswereld daargestel. Die Suid Afrikaanse Kwaliteitsinstituut (SAQI) het in 1997 ' $n$ Suid Afrikaanse eweknie ontwikkel. Die Suid Afrikaanse Kwaliteitstoekenning is deur die administrateurs van eersgenoemde pryse aanvaar. Die lokale Kwaliteitstoekennings word tans deur die Suid Afrikaanse Uitmuntentheidfondasie geadministreer. Die Kwaliteitstoekenning model kan gebruik word om self-meting toe te pas met die doel om besigheids prestasie te verbeter. Hierdie geskrif stel die Suid Afrikaanse model daar stel en verduidelik hoe dit vir strategiese beplanning toegepas kan word. 


\section{INTRODUCTION}

Since the change of Government in 1994, South Africa has found itself in a new competitive situation. Sanctions have disappeared and competitive imports have returned. International competition implies that South African business must become competitive and globalise to survive. (McDowell [6] 41). The country has had to review its strategy as to its world market place and thus its needs (Carruthers [2]). Where to start? It was quite logical to look at the rest of the advancing world. What are they doing? Quality is on everyone's checklist for strategic planning in gaining the competitive edge. What is quality and how does one focus? National awards based on sound quality principles have been a major impetus for countries striving for the competitive edge.

In the USA the Malcolm Baldrige National Quality Award (MBNQA) (Aquilano et al [1] 169) and in Europe the European Foundation for Quality Management (EFQM) Award (EQA) (Slack et al [9] 836) give accredited direction in their own countries. Japan has its Deming Prize, that has been presented for quality achievements since 1951 (Schonberger and Knod [9] 62). South African companies looked at these, but required their own compass for internal and international recognition.

In August 1997, the South African Quality Institute (SAQI) launched the South African Business* Excellence Model (SAB*EM). The SAB*EM is the basis of the national South African Excellence Award. This model is a full hybrid of the MBNQA and the EQA. Certain additional requirements were added to meet South African needs. The SAB*EM was deliberated and developed with the knowledge of the governing bodies of the MBNQA (National Institute of Standards and Technology - NIST) and of the EFQM (European Foundation for Quality). SAQI holds the copyright of the model, whilst the South African Excellence Foundation has the rights to role out and manage the model. In this paper, the SAE Model is not analysed, but taken as given.

The SAE Model (as are the other excellence models) is a tool that can be used to direct strategic planning. The Model has a self assessment approach as the starting point to world class performance. (Carruthers [3] 6).

The elements of this paper are:

Business Excellence and its History

The South African Excellence Model

Strategic Planning

Measuring Excellence using Models

Prioritising Strategy Plans

Getting Started. (The paper is also presented in PowerPoint format, available from the author)

\section{OBJECTIVE}

This aim of the paper is to explain the South African Excellence Model and how it can be used as a tool for measuring current business excellence levels in order to plan and direct improvement strategies.

Footnote: * The word "Business" has since been removed from the model and foundation names, as the model has also been made applicable to non-profit organisations in South Africa. Hence SABEM has become SAEM and SABEF has become SAEF. 


\section{BUSINESS EXCELLENCE AND ITS HISTORY}

After the Second World War Japan had to restructure its economy. Japanese goods were recognised as being of inferior quality. Japanese corporations had to devise strategies to enable them to make their mark in the competitive world market. (Not very different from the current South African position, albeit for different reasons.) A main strategy was to improve quality. For this purpose quality specialists, such as Juran, Deming, Ishikawa and Taguchi were consulted. (Schonberger and Knod [9] 77-82). The results achieved in applying their recommendations were quite conclusive. Japan forged ahead in world markets. The Japanese Union of Scientists and Engineers turned the principles and philosophies of quality into a competition or award system; the Deming award, in 1951. By competing for this award, companies were having to improve their quality by using a given set of measurement criteria as their business excellence focus. The Deming Award is recognised as the first national Business Excellence award.

By the early eighties, Japanese goods were making substantial inroads into the markets in the United States. Initially the US companies ignored the issue, believing that the matter was one of the Japanese work culture that would not really affect them. When Japanese companies however started making defunct US companies successful, this became real reason for concern.

The thought that Japanese people worked harder and were paid less could no longer be considered the reason for Japanese market success. American companies, managed by Japanese, using the quality and business excellence philosophies were becoming a real threat in the American economy. The quality philosophies and cultures had to be taken seriously. On 20 August 1987 (exactly 10 years before the publishing of the SABEM) President Reagan signed Public Law 100-107, the Malcolm Baldrige (a former secretary of Commerce) National Quality Improvement Act. This lead to the establishment of the MBNQA that would give recognition to total quality in American Industry. (Schonberger and Knod [9] 63). This award is based on seven criteria that need to be measured in order to communicate the level of business excellence being attained. The criteria today are not the same as those initially promulgated for the 1988 award. They are continuously reviewed for potential improvement. The General Accounting Office (GAO), the investigative arm of Congress, has studied the data from MBNQA finalists and found strong correlation between the Business Excellence and Quality. Quality minded companies showed better improvement after the application of Total Quality Management/Business Excellence programmes.

Not to be left behind, the Western European countries set out (1988) to spur their own organisations to the competitive edge. They set up the European Foundation for Quality Management and produced the EQA (European Quality Award) in 1992. Their model consists of nine criteria. (Slack et al [10] 836).

In 1994 South Africa had to effectively restart competitiveness in the global arena. Many companies, especially those with international affiliations decided that the Baldrige or EQA route to the competitive edge would be advantageous. This however posed a practical problem, as South Africa is not a participating country in either of these awards. In addition, who was to say whether the EQA or MBNQA (or other award) would be more practical or more marketable. With this in mind, SAQI initiated a project to establish a suitable South African award. After a two year promotional search they obtained support and intellectual sponsorship from several large South African organisations who jointly with $\mathrm{SAQI}$ as the project leaders developed the SAB*EM and subsequently established the $\mathrm{SAB} * \mathrm{EF}$. investigate the issue. Thus $\mathrm{SAQI}$ investigated the available quality awards in conjunction with the administrators of the said awards. As stated in the introduction to this paper, the South African Business* Excellence Model was inaugurated in August 1997. 
The South African Excellence Model has 11 criteria. These criteria cover the spectrum of the business environment. These details of the criteria and sub-criteria are derived from the requirements from, i.a., the EFQM and the MBNQA criteria. The 11 criteria follow in Table 1.

Table 1: The South African Excellence Model: Criteria

\begin{tabular}{|c|c|c|}
\hline \# & Criterion Name and weight & Criterion Definition \\
\hline 1 & LEADERSHIP & $\begin{array}{l}\text { How the behaviour and actions of the executive team } \\
\text { and all the other leaders inspire, support and promote a } \\
\text { culture of Business Excellence. }\end{array}$ \\
\hline 2 & $\begin{array}{l}\text { POLICY AND STRATEGY } \\
\qquad \%\end{array}$ & $\begin{array}{l}\text { How the organisation formulates, deploys, reviews and } \\
\text { turns policy and strategy into plans and actions. }\end{array}$ \\
\hline 3 & $\begin{array}{l}\text { CUSTOMER AND MARKET } \\
\text { FOCUS }\end{array}$ & $\begin{array}{l}\text { How the organisation determines needs, requirements } \\
\text { and expectations; enhances relationships, and } \\
\text { determines satisfaction of customers and markets. }\end{array}$ \\
\hline 4 & PEOPLE MANAGEMENT 7\% & $\begin{array}{l}\text { How the organisation releases the full potential of its } \\
\text { people. }\end{array}$ \\
\hline 5 & $\begin{array}{l}\text { RESOURCE AND } \\
\text { INFORMATION } \\
\text { MANAGEMENT }\end{array}$ & $\begin{array}{l}\text { How the organisation manages and uses resources and } \\
\text { information effectively and efficiently. }\end{array}$ \\
\hline 6 & PROCESSES & $\begin{array}{l}\text { How the organisation identifies, manages, reviews and } \\
\text { improves its processes. }\end{array}$ \\
\hline 7 & IMPACT ON SOCIETY & $\begin{array}{l}\text { What the organisation is achieving in satisfying the } \\
\text { needs and the expectations of the local, national and } \\
\text { international, community at large (as appropriate). This } \\
\text { includes the perception of the organisation's approach } \\
\text { to: } \\
\text { - Quality of Life } \\
\text { - Environment and the Conservation of Global } \\
\text { Resources } \\
\text { - Organisation's own Internal Measures of } \\
\text { Effectiveness } \\
\text { - Its Relations with Authorities \& Bodies which Affect } \\
\text { and Regulate its Business. }\end{array}$ \\
\hline 8 & $\begin{array}{r}\text { CUSTOMER SATISFACTION } \\
17 \% \\
\end{array}$ & $\begin{array}{l}\text { What the organisation is achieving in relation to the } \\
\text { satisfaction of its external customers. }\end{array}$ \\
\hline 9 & PEOPLE SATISFACTION $\mathbf{9 \%}$ & $\begin{array}{l}\text { What the organisation is achieving in relation to the } \\
\text { satisfaction of its people. }\end{array}$ \\
\hline 10 & $\begin{array}{l}\text { SUPPLIER AND } \\
\text { PARTNERSHIP } \\
\text { PERFORMANCE }\end{array}$ & $\begin{array}{l}\text { What the organisation is achieving in relation to the } \\
\text { management of supplier and partnering processes }\end{array}$ \\
\hline 11 & BUSINESS RESULTS & $\begin{array}{l}\text { What the organisation is achieving in relation to its } \\
\text { planned business objectives and in satisfying the needs } \\
\text { and expectations of everyone with financial interest or } \\
\text { other stake in the organisation. }\end{array}$ \\
\hline
\end{tabular}


The criteria and their definitions outline the issues that one would expect to improve, in order to reach world class bench marks. Based on analyses of other awards and past winners, the criteria have been given weights (see Table 1). These weights further assist would be participants. In order to make the criteria more useful, they are divided into criterion parts, that lead to more key words and focus issues.

An example follows for the criterion "Customer Satisfaction".

In this criterion, there are two parts. Each has key words or issues which guide the organisation as to issues it should investigate. The sub-criteria and some key words follow in Table 2.

Table 2: Parts of the Criterion "Customer Satisfaction"

\begin{tabular}{|l|l|l|}
\hline Part \# & \multicolumn{1}{|c|}{ Criterion Part Description } & \multicolumn{1}{c|}{ Some Key Thoughts } \\
\hline a. & $\begin{array}{l}\text { The customer's perception of the } \\
\text { organisation's products, services and } \\
\text { customer relationships }\end{array}$ & $\begin{array}{l}\text { Overall image - accessibility, ethics, etc } \\
\text { Sales and after sales support - capabilities, } \\
\text { complaint handling, product training, } \\
\text { reliability, etc } \\
\text { Loyalty - intention to repurchase, willingness } \\
\text { to recommend the organisation, etc } \\
\text { etc. }\end{array}$ \\
\hline b. & $\begin{array}{l}\text { Additional measurements relating to } \\
\text { the satisfaction of the organisation's } \\
\text { customers }\end{array}$ & $\begin{array}{l}\text { Products and Services - competitiveness, } \\
\text { Defect error and rejection rates, time to } \\
\text { market, number of complaints, etc } \\
\text { Sales and after sales support - demand for } \\
\text { training, response rate, success rate, etc } \\
\text { etc. }\end{array}$ \\
\hline
\end{tabular}

Source: SAEF [8]

The SAEM Criteria are depicted in a diagram similar to that of the EFQM (Carruthers, [3] 8) as Figure 1. The model defined by the SAEF has been adorned in colourful ethnic patterns. This gives an aesthetic effect not unsimilar to that achieved by the Ndebele tribe in covering their homes with mural paintings. The intention of this approach has been to give the model a clear South African identity. The diagram shown, is purely in block format to convey content.

There are two key differences between the ISO 9000 approach and the business excellence model approach. The first is that the business excellence approach focuses on all aspects of business, not just the execution processes as in the ISO 9000 approach. The second major difference is that the business excellence model is divided into two distinct areas, "ENABLERS", i.e. those processes that are put in place to enable something to happen and "RESULTS", i.e. those means that deal with the outcomes of the "ENABLERS". These areas are depicted in Figure 1. (The ISO 9000 system only looks at enabling processes). This approach looks at whether the right issues have been addressed in the right way, to get desired results. People or employee issues play a major role in business excellence. It has been said that a good ISO 9001 would only achieve a $26 \%$ business excellence total (SAEF [8]) but if one adds the "People weights" to this $26 \%$, i.e. the $9 \%$ and $9 \%$ we already see $44 \%$. A holistic Total Quality Management approach has been catered for in the business excellence systems. 


\section{STRATEGIC PLANNING}

Before one can commence with strategic planning, two main elements of information are required. One needs to know where one currently is, and, where one would like to be. Once these two elements are known, one can start the strategic planning process. These two elements define the missing gap. It is often referred to as "Gap Analysis" (Slack et al; [10] 857). This is similar to planning a journey. One knows where one is and one knows where one wishes to go. Now one can plan how one is going to get across the gap to one's destination.

Where the organisation would like to be, is generally set out in the Vision and Mission statements of a company (Goetsch and Davis [5] 80). An example of such a vision statement is given (Goetsch and Davis [5] 78) for the Institute for Corporate Competitiveness, as:

"The Institute for Corporate Competitiveness will be recognized by its customers as the provider of choice for organizational development products that are the best in the world."

This is where the Institute for Corporate Competitiveness wishes to see itself placed in the future.

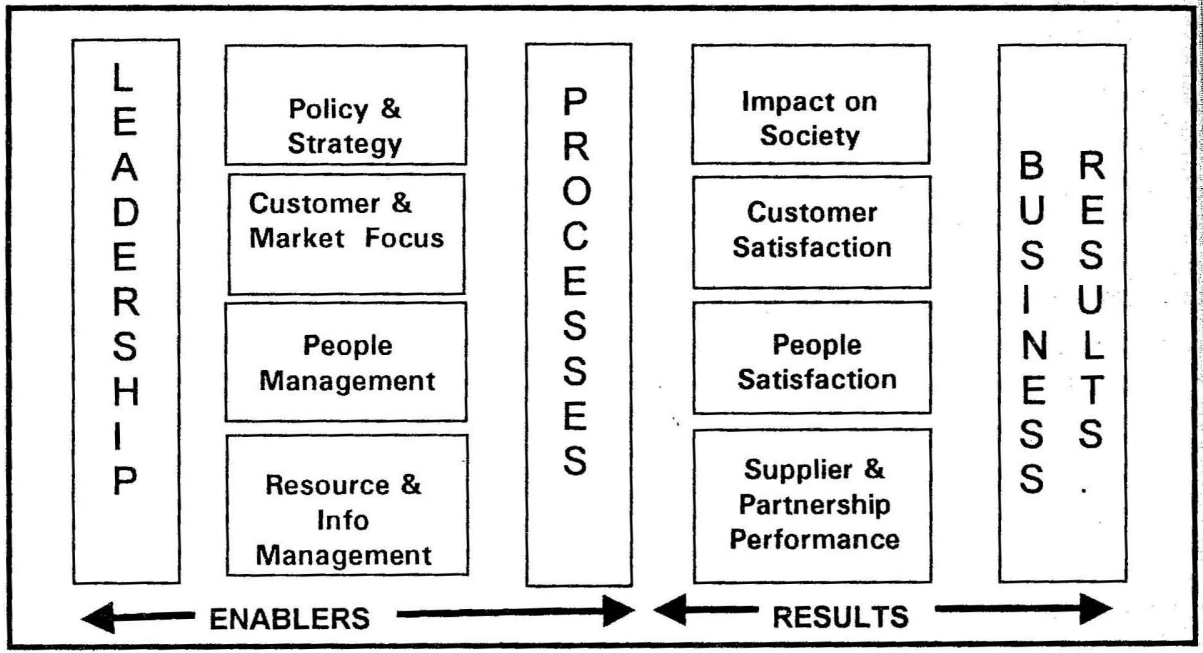

Figure 1: The South African Excellence Model

Source: SAEF [8]

(Copyright of this model rests with SAQI, whilst SAEF have the rights to develop and market it)

In order to know where one is, measurement is required. What must be measured? The criteria that affect the business excellence must be defined and measured against some set bench marks. A SWOT (Strengths, Weaknesses, Opportunities and Threats) analysis is usually the first step in determining where the company is (Goetsh and Davis [5] 75). What are the organisation's strengths, weaknesses, etc.? This SWOT analysis is required, but it does not focus on what needs be analysed. This is where the business excellence model becomes the useful tool.

The business excellence models have all focused on specifying which criteria should be analysed for the competitive edge analyses. The criteria have been defined to enable one to do an analysis of a company. Each criterion will focus towards important strong and weak points in the organisation. The definitions of the important criteria for business excellence have been set. 
With the then given "know where one currently is, and, where one would like to be", the focus is in the right area, and strategic planning can start. The next question is the "how much" or measurement issue of where one is. To improve, you must be able to measure before and after. This is where the business excellence models have another useful tool - a self-assessment system. Measurement systems have been designed to enable one to measure one's current position in macro criteria.

\section{MEASURING EXCELLENCE USING MODELS}

For both the EFQ and the SAE Models a set of simple questions have been devised and tested for each criterion. These questions have been devised in such a way as to minimise subjectiveness. A question such as: "Does your company satisfy your training or development needs?" is open to interpretation and subjectiveness by the respondent. On the other hand a question such as "Is there a comprehensive system that analyses training needs and accomplishments of individuals in the company?" can only be answered as "yes", or "no", or "some degree of yes". The scoring mechanism of the stated models caters for the "some degree" answers. In essence, a question would be answered: "A, B, C or D". These answers are categorised to the score which would be allocated for an answer, as shown in Table 3.

\section{Table 3: Excellence Model Scoring Mechanism}

\begin{tabular}{|l|l|l|}
\hline Answer & Implied answer & Value in points \\
\hline A & Yes, our company system is a world bench mark & 100 \\
\hline B & We have a system, but it is not applied to its full potential & 67 \\
\hline C & We occasionally try something, with some improvement results & 33 \\
\hline D & No, not really started & 0 \\
\hline
\end{tabular}

This table is taken from the concept of the EQA self assessment system, but has been paraphrased. A set of questions has been set up for each criterion in the model. The answer values are simply added, then averaged by the number of questions for the specific criteria to give a percentage for the criterion.

Example: Six questions are posed for a specific criterion and are answered. The total score is found to be 320 . This would give a percentage of $320 / 6 \times 100=53 \%$. (SABEF [8]), (EFQM [4])

In this manner the scores for each criterion can be determined (possibly by using a stratified management and worker level sample) and used as a base line for the company. Some proponents may weight these percentages with the criterion weights from Table 1, whilst most will use them as is. It should be remembered that these scores are only indicative scores in a so-called Macro Measurement system.

Scores can be represented in wagon wheel format for communication purposes. Figure 2 is a fabricated example of such a wagon wheel for MYCO (Pty) Ltd. (SABEF [8]), (EFQM [4]). These scores can then be discussed at strategic planning.

One can subsequently derive micro measurement systems for criterion parts or issues where strategic opportunities have been identified in the Macro Measurement system. These micro measurement systems will obviously differ from organisation to organisation. 


\section{PRIORITISING STRATEGIES}

The prioritising of strategies is a simple matter of a Pareto approach. It is recommended that the lowest percentages on the wagon wheel be analysed as the potential priority weaknesses in the organisation. In the given example (Figure 2) one sees that "People Satisfaction" has a lower rating than any of the other criteria. Also seen to be low is "People Management".

It would appear that these two criteria are linked and need some new strategies. The strategies wil of necessity stem from management themselves, as no text book can prescribe a strategy for al given sets of circumstances. Some guidelines have nevertheless been made available by the Excellence/Quality Foundations themselves. One should enquire directly to them for the information.

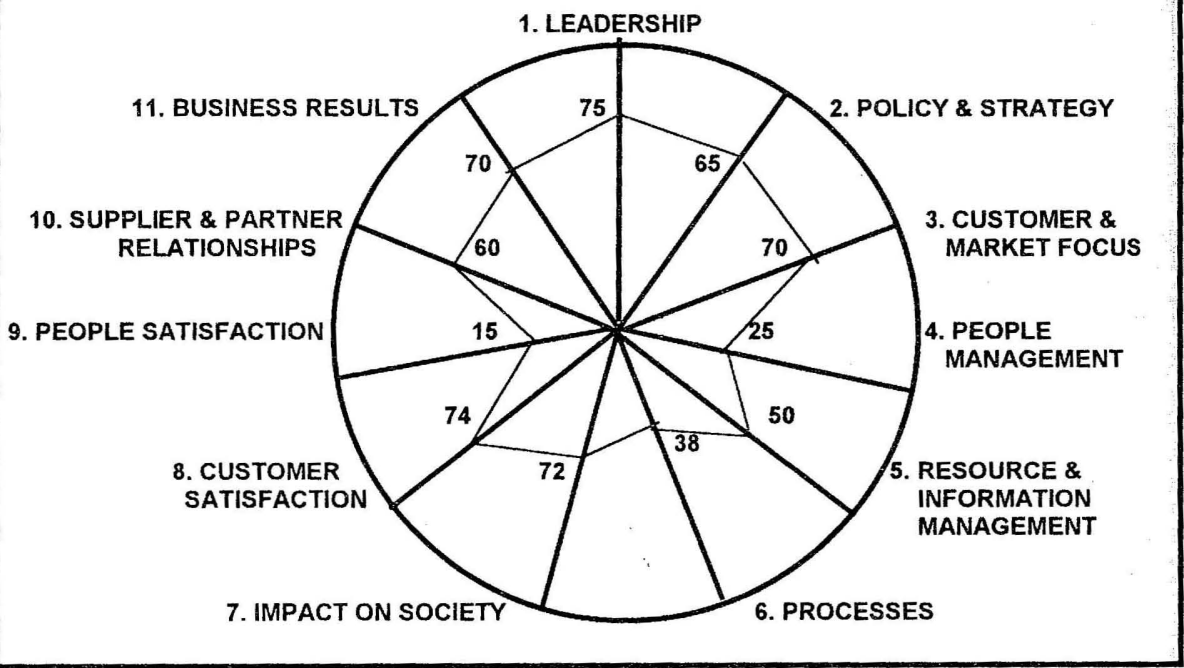

Figure 2: The Wagon Wheel Of Criterion Scores For "Myco (Pty) Ltd"

dated : 2 July 1999

\section{GETTING STARTED}

Strategic planning is of necessity a top management function. It goes without saying that top management must be committed to the task. In the same way, if business excellence models are to be useful, top management must be committed to using, supporting and developing such measures as may be required.

The following steps are suggested as a means to use the business excellence model as a tool for setting about strategic planning. Individuals would tend to adapt these steps to their own personal needs and liking. Nevertheless the basic steps would stay relevant. 


\begin{tabular}{|c|c|}
\hline 1 & $\begin{array}{l}\text { Have top management agree to the value and use of the self-assessment tool. (Specify the } \\
\text { model to be used in one's country/organisation.) }\end{array}$ \\
\hline 2 & Obtain the model's specified assessment handbook. \\
\hline 3 & Appoint a self-assessment project manager. Train the person in the model and its criteria. \\
\hline 4 & Communicate the tool to all in the company, explaining that their input adds value. \\
\hline 5 & $\begin{array}{l}\text { Decide and communicate key dates for the self-assessment programme, taking key dates } \\
\text { for strategic planning into account. }\end{array}$ \\
\hline 6 & Design the sample population required for scoring of the company criterion values. \\
\hline 7 & the assessment questionnaires. \\
\hline 8 & Collect the completed questionnaires. \\
\hline 9 & Compute the results by organisation level category. \\
\hline 10 & Combine the results of the scores as per agreed design (step 4 above) \\
\hline 11 & Communicate the results to the Strategy Planning team. \\
\hline
\end{tabular}

As in any project the person responsible for the assessment, i.e. the project manager will decide the details of the process. The motivational and morale issues of such assessment must be taken into account. Questioning employees about employee satisfaction will of necessity lead to an expectation of improvement. If the organisation does not intend to use the self-assessment information, it would be better not to embark upon this route. Employee backlash can provide negative impact.

\section{CONCLUSION}

The SAEM has been designed to allow South African organisations to compete in the global market. It has set a very real focus for self-assessment. Self-assessment is in itself a means, not an objective. Self assessment allows organisations to plan development in wanting areas. The SAE Model also gives guidelines for an award entry for organisations who wish to demonstrate that they are on the cutting edge of the world class competitiveness, by winning such an Excellence award.

Such an award must not be seen as an ultimate objective as the world about us is in a state of constant change. Winning the award should at best be seen as a platform for future improvement in order to maintain the competitive edge. There are a few cases of companies winning the EQA or MBNQA and going out of business shortly thereafter.

Use the models and self-assessment tools as a means of focus. 


\section{BIBLIOGRAPHY AND REFERENCES}

[1] Aquilano, N. J; Chase, R. B and Davis, M. M; Fundamentals of Operations Management; $2^{\text {nd }}$ Edition, 1995; Irwin, Chicago.

[2] Carruthers, Dr M; Management Today; Quality in the Next Ten Years; Vol. 13 No 7; August 1997; R Havenga \& Associates, Northcliff, Johannesburg.

[3] Carruthers, $\mathrm{Dr} \mathrm{M}$; The Review for CEO,s: Self Assessment: the road to world class performance; Vol. 1 No 4; April 1997; R Havenga \& Associates, Northcliff, Johannesburg.

[4] EFQM; What is Self Assessment? Your Handbook; $3^{\text {rd }}$ edition 1996; EFQM, Brussels; Gower Publishing, England.

[5] Goetsch, D.L. and Davis, S.B; Introduction to Total Quality Management; $2^{\text {nd }}$ Edition, 1997; Prentice Hall, Upper Saddle River, New Jersey

[6] McDowell, Dr M; Management Today; South African Industry Faces Global Competition; Vol. 13 No 8; September 1997; Havenga, R. \& Associates, Northcliff, Johannesburg.

[7] SABEF; What is Self Assessment? Your Handbook; 1st Edition, 1998; S A Quality Institute, Pretoria South Africa. (m-powa http://m-powa com)

[8] SAEF; The South African Business Excellence Model - Criteria and General Guidelines; 3nd Edition, 1998; S A Quality Institute, Pretoria South Africa.

[9] Schonberger, R. J; Knod Jr, E. M; Operations Management : Customer - Focussed Principles; $6^{\text {th }}$ Edition, 1997; Irwin/McGraw Hill, Boston.

[10] Slack, N; Chambers, S; Harland, C; Harrison, A and Johnston R; Operations Management; $1^{\text {st }}$ Edition, 1995; Pitman. London. 